\title{
Effects of the Monetisation Policy on employee performance in the Nigerian civil service
}

\begin{tabular}{|c|c|}
\hline $\begin{array}{l}\text { Authors: } \\
\text { Damian C. Uk } \\
\text { Chiemeka On }\end{array}$ & 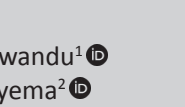 \\
\hline $\begin{array}{l}\text { Affiliations: } \\
{ }^{1} \text { School of } \mathrm{Pu}\end{array}$ & \\
\hline $\begin{array}{l}\text { Management } \\
\text { and Public Po } \\
\text { Business and } \\
\text { University of } \\
\text { Johannesburg }\end{array}$ & $\begin{array}{l}\text { Governance } \\
\text { licy, College of } \\
\text { Economics, } \\
\text { Johannesburg, } \\
\text {, South Africa }\end{array}$ \\
\hline $\begin{array}{l}{ }^{2} \text { Department } \\
\text { College of Soc } \\
\text { Imo State Uni } \\
\text { Owerri, Niger }\end{array}$ & $\begin{array}{l}\text { of Sociology, } \\
\text { cial Sciences, } \\
\text { versity, } \\
\text { ia }\end{array}$ \\
\hline $\begin{array}{l}\text { Correspondin } \\
\text { Damian Ukwa } \\
\text { damianu@uj. }\end{array}$ & $\begin{array}{l}\text { g author: } \\
\text { ndu, } \\
\text { ac.za }\end{array}$ \\
\hline $\begin{array}{l}\text { Dates: } \\
\text { Received: } 22 \\
\text { Accepted: } 02 \\
\text { Published: } 28\end{array}$ & $\begin{array}{l}\text { Eeb. } 2019 \\
\text { July } 2019 \\
\text { Aug. } 2019\end{array}$ \\
\hline $\begin{array}{l}\text { How to cite th } \\
\text { Ukwandu, D.C } \\
\text { 2019, 'Effects } \\
\text { Monetisation } \\
\text { employee per } \\
\text { Nigerian civil } \\
\text { Public Service } \\
\text { Performance } \\
\text { a271. https:// } \\
\text { 10.4102/apsd }\end{array}$ & $\begin{array}{l}\text { is article: } \\
\text { \& Onyema, C., } \\
\text { of the } \\
\text { Policy on } \\
\text { formance in the } \\
\text { service', Africa's } \\
\text { Delivery and } \\
\text { Review } 7(1) \text {, } \\
\text { doi.org/ } \\
\text { pr.v7i1.271 }\end{array}$ \\
\hline $\begin{array}{l}\text { Copyright: } \\
\text { (C) 2019. The A } \\
\text { Licensee: AOS } \\
\text { is licensed und } \\
\text { Creative Comr } \\
\text { Attribution Lic }\end{array}$ & $\begin{array}{l}\text { Authors. } \\
\text { IS. This work } \\
\text { der the } \\
\text { mons } \\
\text { ense. }\end{array}$ \\
\hline Read online: & \\
\hline 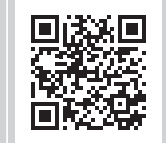 & $\begin{array}{l}\text { Scan this QR } \\
\text { code with your } \\
\text { smart phone or } \\
\text { mobile device } \\
\text { to read online. }\end{array}$ \\
\hline
\end{tabular}

Authors:

Affiliations:

${ }^{1}$ School of Public

anagement, Governance Business and Economics,

University of Johannesburg,

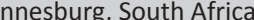

Department of Sociology, Imo State University,

Corresponding author:

Damian Ukwandu,

damianu@uj.ac.za

Dates:

How to cite this article:

2019, 'Effects of the

Monetisation Policy on

employee performance in the

Performance Review 7(1)

a271. https://doi.org/

Copyright:

C) 2019. The Authors.

Licensee: AOSIS. This work

licensed under the
Background: This article examined the enormous financial burden placed on the Federal Government of Nigeria by the management and maintenance of its civil servants. The cost of governance in Nigeria continues to rise mainly because of the provision of fringe benefits (such as free residential accommodation, medical services, transport facilities and utilities, including telephone service, water and electricity) to public servants. Yet, public employees' performance continues to decline, which leads to low levels of human and physical infrastructure development.

Aim: This article examines the effects of the rising cost of governance in Nigeria and how to enhance employee performance. The article interrogates the effects of the monetisation of fringe benefits policy (the Monetisation Policy) of the Obasanjo Administration (2003-2007).

Setting: The study was conducted in the Federal Civil Service Secretariat in Owerri, Imo State, Nigeria.

Methods: This article is anchored in social exchange theory. The study participants comprised 1007 federal civil servants selected from 32 federal establishments. The participants were selected using the total population sampling technique. A structured questionnaire with a reliability coefficient estimate of 0.742 was used to generate the data for the study. The Statistical Package for the Social Sciences (SPSS) aided the presentation and analysis of data relating to the research objectives using frequency distribution tables and testing research hypotheses with chi-square statistics and Pearson's product-moment correlation statistic.

Results: The findings revealed that the Monetisation Policy has helped to enhance employee payment packages. A statistically significant positive correlation was found between high monetised benefits and high employee performance. The study found that the Monetisation Policy has had positive effects on employee performance in the federal civil service in Imo State.

Conclusion: This study concludes that the Monetisation Policy has helped to enhance employee motivation and morale, and to reduce employee work-related stress, which are vital indicators of work efficiency. These factors do not only affect the contextual performance of the civil servants, but also predispose their task performance. The researchers recommend that the Monetisation Policy should be sustained. It is also recommended that the government should introduce other measures aimed at enhancing the motivation of employees who receive lower monetised benefits so as to further improve the overall performance of the Nigerian civil service.

Keywords: Monetisation; fringe benefits; civil service; employee performance; Nigeria.

\section{Introduction}

\section{Background and problem statement}

Civil service can be described as the 'wheel' on which the state and government run. The importance of civil service is easily observed in policymaking, fiscal management (such as revenue generation and budgeting), and providing access to public goods and services. Without civil service, it would be difficult to plan, coordinate and implement policies and programmes that would improve the living conditions of the citizenry and achieve sustainable national development. Therefore, a skilled, motivated and efficient civil service with professional ethos is a necessary condition for good governance (Schiavo-Campo \& Sundaram 2001:12). The quality of life in any country depends in many ways on those who work for the government (civil servants) and the way they carry out their work (performance). According to Besley and Persson (2010), the effective functioning of the government bureaucracy is an important determinant of poverty, inequality 
and economic growth. Calderon (2009:3) asserted that the quality of infrastructure in a country mirrors the quality of the civil service of that country. Therefore, the role of the civil service employees in producing public outcomes is often used as a measure of their performance (Schacter 2002:4).

In recent times, there have been many criticisms against the Nigerian civil service. Much of the criticism against the Nigerian civil service is largely because of its failure to discharge its statutory mandates and because of the high rate of bureaucratic corruption prevalent in the service. The inability of the civil service to respond to public demands through demonstrable results, such as good healthcare system, quality public schools system, good sanitation system, proper supervision of government contracts and full implementation of annual budgets, has made public criticism so terse.

Statistical facts, such as Nigeria's Human Capital Index, can be used to illustrate the low and / or declining performance of the civil service. For instance, the poverty rate in Nigeria rose in the past three decades: from $27.2 \%$ in 1980 to $46.3 \%$ in 1985 , and in 1992 decreased to $42.7 \%$. By 1996, the poverty rate in Nigeria had risen to $65.6 \%$ (National Bureau of Statistics 2012:8). This situation is because of the poor and/or nonimplementation of policies and programmes aimed at addressing the alarming rate of poverty in the country. It is against this background of poor performance that spirited calls are made for reform in the civil service.

Over the years, successive Nigerian governments have initiated reforms aimed at improving the capacity of the civil service to deliver public services. The reforms were designed to correct the observed inadequacies of the Nigerian civil service, which include excessive bureaucracy that causes significant delays in service provision, high levels of corruption and low productivity. Some of the civil service reforms that have been undertaken in Nigeria since the 1940s were driven by instituted commissions and panels such as the Hunt Commission of 1934, the Bridges Committee of 1941, the Davis Commission of 1945, the Harragin Commission of 1946, the Gorsuch Commission of 1954 and the Mbanefo Commission of 1959 (Adebayo 2000:7; Ogunna 1999:6). Some others are the Morgan Commission of 1963, the Elliot Grading Team of 1966, the Adebo Commission of 1970, the Udoji Commission of 1974 and the Ayida Panel of 1995 (Adebayo 2000:7; National Salaries, Incomes and Wages Commission 2010:89; Ogunna 1999:6).

One of the more recent reforms is the Public Service Renewal Programme (PSRP), which had the specific objectives of tackling corruption in the civil service, checking the wastage of government resources, stopping undue delays in service delivery, correcting the stagnation at the top echelon of the service and reducing the huge personnel cost. In order to achieve these objectives, the government introduced reform policies such as the Contributory Pension Scheme, the Rationalisation Policy, the Service Compact (SERVICOM), the Due Process Policy and the Monetisation Policy. The latter is the focus of this study.

The main objectives of the Monetisation Policy are to address the ever-rising cost of governance in the country, to curtail the flagrant waste and abuse of government resources, to enhance employee morale and to improve employee performance (Office of the Head of the Civil Services of the Federation [OHCSF] 2013:7). Recent experiences show, however, that the government's recurrent costs are rising instead of dropping. For instance, the recurrent budgetary allocation to the Office of the Secretary to the Government of the Federation rose from N46 200983088 in 2014 (Federal Government of Nigeria 2014). Despite this, there were no significant changes in the performance of Nigerian public employees - judging by the state of key development infrastructure such as electric power supply and public school system, which are still problematic.

The Monetisation Policy was also designed to help counter the dependency syndrome developed by public servants. It was expected that the policy would help to prepare civil servants for post-retirement life. It could be argued that the latter objective had been met to some extent as some categories of civil servants purchased the official houses and cars given to them. Despite this, the policy has created some problems. According to Fayomi (2013:8), the implementation of the Monetisation Policy induced inflation, which reduced the purchasing power and worsened the living standard of civil servants in the Nigerian ministries. Fayomi (2013:9) also stated that the Monetisation Policy has created a negative work attitude in the mainstream civil service because of the discrepancy in the fulfilment of monetisation packages to civil servants in the ministries as compared to public servants in other government agencies and departments. Monetisation has also led to the redundancy of certain categories of staff like drivers, as many government vehicles were sold.

The Monetisation Policy entails a new salary package for civil servants. It should be stated that the policy has led to an increment in the emoluments of civil servants. Nevertheless, the salaries of civil servants are pitiable when compared to those of their counterparts in the private sector. The gap in salaries between the public and private sector is between 300\% and 500\% (Nwanolue \& Iwuoha 2012:6). Within the public sector, the salary of the civil servant is the lowest. For instance, the least paid staff member of the Central Bank of Nigeria earns more than a Grade 13 officer in the civil service. The pay package of a director in the civil service is only $20 \%$ of that of his or her equivalent in the Nigerian National Petroleum Corporation (Federal Republic of Nigeria 1995:6). This may likely cause many civil servants to feel shortchanged, and it could be a probable precursor to the high level of corruption and poor work performance. Hence, it is pertinent to examine the effects of the Monetisation Policy on employee performance in the Nigerian federal civil service. 


\section{Objectives of the study}

The main objective of this study is to investigate the effects of the Monetisation Policy on employee performance in the Nigerian civil service, with particular reference to the federal civil service in Imo State.

The specific objectives of this study are as follows:

- to investigate the effect of the Monetisation Policy on employee pay packages in the federal civil Service in Imo State

- to examine the effect of the Monetisation Policy on employees' attitude towards work in the federal civil service in Imo State

- to ascertain whether the Monetisation Policy has a homogeneous effect on all employees in the federal civil service in Imo State.

\section{Research hypotheses}

The hypotheses of this research are as follows:

- There is a significant relationship between the Monetisation Policy and increased employee performance in the federal civil service in Imo State.

- Employees with higher monetised benefits are more likely to perform better than employees with lower monetised benefits in the federal civil service in Imo State.

\section{Literature review and theoretical framework \\ The concept of monetisation}

The concept of monetisation has its origin in economic literature. Monetisation is simply the process of converting or establishing something into legal tender. The term 'monetisation' is also used to refer to exchanging possessions for cash or cash equivalents, including charging fees for something that used to be free (OMICS International 2014:4). In public sector reform, particularly in Nigeria, monetisation entails converting in-kind entitlements (such as free housing, utilities and transportation) into equivalent cash payments. For instance, the Nigerian government led by President Olusegun Obasanjo during the Fourth Republic initiated a monetisation policy through a reform programme called the PSRP, chiefly for the quantification of public employees' fringe benefits and the payment of the cash value. Prior to the introduction of the Monetisation Policy, public servants in Nigeria used to enjoy many benefits-inkind as part of their benefits of service. These benefits-in-kind included highly subsidised residential accommodation, residential furniture, chauffeur-driven official vehicles (for the top echelon of the service), free medical services and public-funded utilities such as potable water, telephone service and electricity (Federal Ministry of Information and National Orientation 2013:9). Some of these benefits came with allowances such as meal subsidies, furniture allowances, entertainment allowances and motor vehicle maintenance allowances (OHCSF 2013:9). These benefits are usually termed fringe benefits.
The introduction of the Monetisation Policy by President Olusegun Obasanjo was necessitated by the revelation that over $85 \%$ of public sector expenditure in Nigeria went to overhead costs (Fayomi 2013:8). One of the identified reasons for the very high overhead cost, which affected the overall development of the country, was the burden of providing fringe benefits to all categories of public servants. For instance, the government was spending large amounts of resources to purchase, rent, renovate, maintain and furnish residential accommodation, and to purchase, fuel and maintain official vehicles for public servants. The provision of these fringe benefits contributed to the escalating cost of maintaining the civil service. As Aluko (2003:12) observed, although the civil servants constitute approximately $20 \%$ of the population of Nigeria, to maintain them took up between $60 \%$ and $70 \%$ of the annual national budget. The Monetisation Policy was therefore initiated to reduce the cost of running and maintaining the civil service. The policy was equally aimed at curtailing the waste, misuse and abuse of public resources. Other objectives of the Monetisation Policy include encouraging a maintenance culture and discipline among public servants, and to discourage their dependency syndrome. Ultimately, the policy was initiated to conserve funds for capital expenditure (Aluko 2003:12).

The Monetisation Policy took effect from 01 July 2003 with the passage of the Certain Political, Public and Judicial Office Holders (Salaries and Allowances, etc.) Act of 2002. The main feature of the Monetisation Policy is that individual pay cheques would henceforth comprise monetised fringe benefits such as housing, utilities and transportation.

TABLE 1: Approved harmonised fringe benefits and allowances for federal civil servants under the Monetisation Policy.

\begin{tabular}{|c|c|c|c|}
\hline$S / N$ & Type of allowance & Grade level & Rate per annum \\
\hline \multirow[t]{3}{*}{1.} & Accommodation & $01-06$ & $50 \%$ of annual basic salary \\
\hline & & 07-14 & $60 \%$ of annual basic salary \\
\hline & & 15 and above & $75 \%$ of annual basic salary \\
\hline 2. & Transportation & $01-17$ & $25 \%$ of annual basic salary \\
\hline \multirow[t]{5}{*}{3.} & Meal subsidy & $01-06$ & $\$ 6000.00$ \\
\hline & & 07-10 & 88400.00 \\
\hline & & $12-14$ & $\$ 9600.00$ \\
\hline & & $15-17$ & $\mathrm{~N} 10800.00$ \\
\hline & & Permanent secretary (PS) & N16 200.00 \\
\hline \multirow[t]{2}{*}{4.} & Utility & $01-16$ & $15 \%$ of annual basic salary \\
\hline & & 17 and above & $20 \%$ of annual basic salary \\
\hline \multirow[t]{3}{*}{5.} & Domestic servant & 15 & 1. GL. 3 Step 8 \\
\hline & & $16-17$ & 2. GL. 3 Step 8 \\
\hline & & PS and above & 3. GL. 3 Step 8 \\
\hline 6. & Leave grant & 01 and above & $10 \%$ of annual basic salary \\
\hline 7. & Medical & 01 and above & $10 \%$ of annual basic salary \\
\hline \multirow[t]{2}{*}{8.} & Furniture allowance & $01-06$ & NIL \\
\hline & & 17 and above & $\begin{array}{l}200 \% \text { in } 5 \text { years } \\
\text { (i.e. } 40 \% \text { per annum) }\end{array}$ \\
\hline \multirow[t]{3}{*}{9.} & Vehicle loan & 01-05 & $100 \%$ of annual basic salary \\
\hline & & $06-07$ & $150 \%$ of annual basic salary \\
\hline & & 08 and above & $200 \%$ of annual basic salary \\
\hline 10. & Driver & 17 and above & 1. GL. 3 Step 8 \\
\hline
\end{tabular}

Source: Federal Ministry of Information and National Orientation, 2013, The Obasanjo reforms: Monetisation policy, Production, Publications \& Documentation Department, Abuja $\mathrm{S} / \mathrm{N}$, serial number; GL, grade level; ${ }^{*}$ Naira; NIL, zero. 
Thereafter, employees would be responsible for all their expenses relating to the monetised benefits (OHCSF 2013:5).

\section{Employee performance}

Employee performance is one of the most important concepts in organisational studies. This is because the achievement of organisational goals is dependent on the performance of the employees (Campbell 1990:8). Employee performance describes how well employees execute the job-related activities expected of them. One key feature of job performance is that it is directed towards the goals of the organisation. Campbell (1990:8) defined employee job performance as behaviour. He proposed a multi-factor approach to defining and predicting job performance, which consists of examining an employee's task-specific behaviour, non-task-specific behaviour, commitment, personal discipline and willingness to assist co-workers. Roe (1999:9) emphasised that employee performance falls within process and outcome aspects. Discussions of employee performance usually revolve around two dimensions, namely task performance and contextual performance. Williams and Karau (1991:13) stated that task performance covers an employee's contribution to organisational performance through actions that address the requirements as specified in job descriptions. For Werner (2000), task performance consists of behaviours that are directly involved in producing goods or services. Essentially, task performance refers to the effectiveness with which employees perform activities that contribute to the organisation's technical core (Borman \& Motowildo 1993:12).

The second dimension of performance, which is contextual performance, is defined as performance that helps to shape the social and psychological context of the organisation (Borman \& Motowildo 1993:15). Contextual performance is a multi-dimensional concept (Van Dyne \& LePine 1988) that serves as critical catalyst for tasks and processes. It is usually 'voluntary' in nature. Examples of contextual performance include the following: prescribed rules and procedures (such as Civil Service Rules and the Code of Conduct for Public Officers), assisting or cooperating with co-workers, job dedication and enthusiasm and volunteering for extra work (Borman \& Motowildo 1997:14). With regard to rules, the word 'voluntary' implies that the employee, despite being aware of the implications of non-adherence to prescribed rules, must decide the course of action to follow.

Motowildo and Schmit (1999:23) articulated that the three major differences between task and contextual performance are as follows: (1) task performance is job specific, whereas contextual performance activities are comparable for all jobs, (2) task performance is in-role behaviour and part of the formal job description, whereas contextual performance is extra-role and discretionary and often not rewarded by the formal reward system and (3) task performance is predicted by ability, whereas contextual performance is predicted by motivation and personality. Organisations customarily highlight the importance of employee task and contextual performance in the evaluation of their staff. The civil service annual appraisal form conveys this importance as it assesses employees' performance based on task and contextual performance. The discussion of employee performance in this study revolves around the two dimensions of performance (task and contextual) as both contribute to the growth of the civil service (Motowildo \& Schmit 1999:23).

However, because of the nature of civil service work that varies according to the different ministries, departments and agencies (MDAs), and because of the different job descriptions in the MDAs, it is often difficult to accurately apply a uniform measure of employee performance based on task performance. For this reason, the researchers emphasise contextual performance indicators in an attempt to measure and aggregate employee performance across the entire civil service.

\section{Monetisation policy and employee performance}

Few studies have investigated the effect of the Monetisation Policy on public sector employees in Nigeria. For instance, Adeleke (2010) investigated the implication of the monetisation of fringe benefits on workers' commitment in AdekunleAjasin University, Ondo State, Nigeria. The study found that the monetisation of fringe benefits did not improve employee welfare because of the rate at which market prices of goods and services were increasing. Adeleke (2010) observed that this affected employee productivity and loyalty towards the university. Saka (2012:14) studied the relationship between output and monetisation of public servants' wages and salary structures. The results showed that the new salary package, which had monetisation as an important component, varied in the right direction with output. The implication is that the new salary package through monetisation increased productivity and output.

Okafor (2014:21) investigated the impact of the Monetisation Policy on organisational citizenship behaviour in Nigeria. The cross-sectional study sought the opinions, perceptions and reactions of respondents relating to the Monetisation Policy and citizenship behaviour constructs of organisational loyalty, organisational compliance and employee conscientiousness. The findings showed that the Monetisation Policy was not positively linked and associated with organisational loyalty. The conclusion of the study was that the policy of monetisation had so far failed to improve organisational citizenship behaviour. Ayapere (2015:16) investigated the effect of the Monetisation Policy on workers in the Nigerian civil service, specifically examining the effect of monetisation on workers' job satisfaction and on workers' attitude towards job performance.

The findings of Ayapere's (2015) study revealed that there was no positive effect of the Monetisation Policy's implementation on workers' attitude towards job performance in the Nigerian civil service, and that the Monetisation Policy had no positive effects on workers' job satisfaction. Ayapere (2015) therefore concluded that monetisation had no positive effect on workers in Nigeria's 
civil service. The mixed results from the above-stated studies, among other reasons, propelled this study. The researchers considered it expedient to continue to deepen the discussion on the relationship between the Monetisation Policy and employee performance, especially within the federal civil service in Nigeria. This is because of the crucial role of the federal civil service in the drive towards achieving sustainable national development.

\section{Theoretical framework}

\section{Social exchange theory}

Theories provide frameworks and foundations for the analysis of any phenomenon. This study considers the social exchange theory to be useful and appropriate in interrogating and explaining the relationship between employers and employees within the context of reforms. The theory is equally helpful in explaining the outcomes of such relationships. This study is therefore anchored in the social exchange theory. The social exchange theory was popularised by Claude Levi-Strauss, George C. Homans and Peter M. Blau, who proposed that social behaviour is the result of an exchange process (Cherry 2016:15).

The purpose of the exchange is principally to maximise benefits and, in the process, minimise costs. According to Cherry (2016:14), the social exchange theory suggests that people value the benefits and costs of each relationship in order to determine how much a relationship is worth. She further stated that social exchange involves more than costbenefit analysis; it involves establishing comparison levels based on social expectations and experiences, and comparing the potential alternatives. The social exchange theory has been applied to organisational settings to provide a basis for understanding the roles that organisations play in creating feelings of employee obligation and proorganisational behaviour such as performance and citizenship (Wayne et al. 2002:16).

Two main streams of research apply the social exchange theory in organisations, namely leader-member exchange (LMX) and perceived organisational support (POS). According to Wayne et al. (2002:23), studies on LMX usually focus on the quality of the exchange (relationship) between the employee and the manager. In contrast, research on POS emphasises the exchange between the employee and the organisation. Essentially, LMX is based on the degree of emotional support and exchange of valued resources derived from the relationship between the supervisor and the employee, while POS is based on the employee's perception of the employer's commitment to them. One key component of the social exchange theory is the norm of reciprocity, which implies that persons who are treated favourably by others are most likely to respond in a positive manner. The norm of reciprocity is a fundamental factor in the exchange relationship between the supervisor and the employee, and between the employee and the organisation.
Dabos and Rousseau (2004:12) emphasised that reciprocity within an organisation refers to the cooperative exchange between employees or between employees and the organisation. Reasoning along this line, employees who are satisfied with the results of their workplace exchanges will be inclined to respond favourably towards the needs or goals of the organisation (Shaw et al. 2009:18). In other words, employees who perceive a high level of organisational support or who have a high-quality relationship (exchange) with the supervisor feel a sense of indebtedness and reciprocate in terms of attitudes and behaviours that benefit the exchange partner.

Another factor that is usually emphasised by social exchange theorists in their studies of organisational partners' exchanges is the perception of organisational justice or fairness. According to Moorman, Blakely and Nichoff (1998:12), justice perception refers to an employee's evaluation of the discretionary actions taken by the organisation, which are indicative of the degree of organisational support. There are four main categories of organisational justice - procedural justice, distributive justice, informational justice and interactional justice - all of which reflect employees' perceptions of outcomes, processes, interpersonal interactions and how employees are treated within the organisation. Greenberg (1990:399) pointed out that perceptions of organisational justice are 'a base requirement for the effective functioning of organizations and the personal satisfaction of the individual they employ'.

In applying the social exchange theory to this study, the researchers hypothesised that irrespective of the goals of a reform policy such as the Monetisation Policy, the perception of the employees regarding their position on the relationship scale would determine whether they would buy into the policy. Employees' perceptions of the policy and its environment would determine how they would adjust their work behaviour towards policy prescriptions. Hence, if employees (i.e. federal civil servants) perceive the Monetisation Policy as a ploy by their employer (the federal government) to withdraw its support to them or to deny them of their entitlements, they would likely respond negatively by exhibiting anti-organisational behaviour (disloyalty, lack of commitment and low performance). If, however, the civil servants perceive the Monetisation Policy to be fair (just) and as an expression of organisational support, they will respond by exhibiting pro-organisational behaviours such as loyalty, commitment, organisational citizenship and high performance. Consequently, the civil servants will consider the success of the federal civil service as their personal priority. Therefore, they will not undermine policies aimed at enhancing organisational efficiency.

\section{Methodology}

This work was designed as a cross-sectional survey and a descriptive study. Cross-sectional surveys aim at collecting information on certain variables in a study population at one point in time. This method is justified by the assumption that 
there are many similar elements in any population. The study is descriptive because it seeks to describe the relationship between two key variables: the Monetisation Policy and civil service employee performance.

\section{Area of the study}

The area of the study is Imo State, which is one of the five states that make up the southeastern region of Nigeria. Imo State is composed of 27 local government areas (LGAs). These 27 LGAs are politically structured into three senatorial zones, namely Orlu, Owerri and Okigwe. Orlu comprises 12 LGAs, Owerri has 9 LGAs, while Okigwe is made up of 6 LGAs.

Based on the 2006 National Population and Housing Census, Imo State has a total population of 3927563 persons. Of this number, 1976471 are men and 1951092 are women. Imo State has a population density of 757.8 persons per square kilometre $\left(\mathrm{km}^{2}\right)$ and covers a land size of 5182.82 $\mathrm{km}^{2}$ (National Population Commission 2010). Imo State is bordered by Anambra State to the north, Delta State to the west, Abia State to the east and Rivers State to the south. The major rivers and lake in Imo State are the Njaba River, Imo River, Otamiri River and Oguta Lake. The major occupations of Imo State inhabitants are civil service, agriculture and commerce.

\section{Population and sample size}

A total survey of the entire study population of 1086 federal civil servants was attempted. However, only 1007 federal civil servants responded adequately to the research questionnaire. Therefore, a sample size of 1007 was used to generate quantitative data for this study. The sample size represents $92.7 \%$ of the study population.

\section{Sampling technique}

The sampling techniques adopted for the study were the purposive sampling technique and the total population sampling technique. The purposive sampling technique was utilised to select 32 federal establishments out of the 64 federal establishments operating in Imo State. This technique was adopted because of the need to select federal establishments that share the common characteristic of being labelled as the federal civil service, that is, those establishments that are regulated by the Federal Civil Service Commission and are subjected primarily to Civil Service Rules. This study adopted the total population sampling technique in administering the questionnaire to the respondents, which included all 1086 employees of the 32 federal civil service organisations.

\section{Instrument for data collection}

The survey data were collected via questionnaire. The research questionnaire consisted of questions designed to elicit the responses of civil servants on the effects of the Monetisation Policy on employee performance in the federal civil service in Imo State. The questionnaire was not cadresensitive; it targeted all cadres of employees. In order to increase the reliability of the data collected with the questionnaire and to avoid ambiguity, the questionnaire was piloted on employees of the Nigeria Customs Service and the Nigeria Immigration Service.

\section{The reliability of the research instrument}

A pilot study adopting a test-retest method was conducted in order to estimate the reliability of the research questionnaire. The pilot study was conducted using 50 respondents selected from two federal establishments (the Nigeria Customs Service and Nigeria Immigration Service), which are not part of the core civil service, and, as such, not involved in the main study. The questionnaire was administered to the pilot study respondents on two separate occasions at an interval of 2 weeks. The data retrieved from the first and second administration were subjected to a reliability test using Cronbach's alpha. The reliability test revealed a coefficient estimate of 0.742 , which indicated a high level of internal consistency of the questionnaire, and therefore justified its reliability as a research instrument.

\section{Methods of data analysis}

The research data were analysed using descriptive and inferential statistics. The descriptive statistics involved the use of frequency and percentage distribution tables to present and analyse the respondents' responses to questionnaire items addressing the research objectives. The research hypotheses were tested with inferential statistics consisting of chi-square statistics and Pearson's product-moment correlation statistic.

\section{Presentation of data and discussion of findings Data presentation and analysis}

This section presents and analyses the survey data. The data presented herein are the responses of 1007 study respondents. The research data are analysed to answer the research objectives. This section also contains the test of research hypotheses. The data on the respondents' socio-demographic characteristics have been omitted for the sake of brevity.

\section{Effect of the Monetisation Policy on employee pay packages}

In order to investigate the effect of the Monetisation Policy on employee pay packages in the federal civil service in Imo State, Nigeria, the respondents were asked whether the Monetisation Policy enhanced their pay package. Data analysis revealed that 59\% (594) of the 1007 respondents responded 'yes', which indicated that the Monetisation Policy has enhanced their pay package, 22.9\% (229) said they were not sure, while $18.3 \%$ (184) said 'no' (Table 1-A1). The majority of respondents therefore confirmed that the Monetisation Policy has helped to enhance employee pay packages in the Nigerian federal civil service. 


\section{Effect of the Monetisation Policy on employees' attitude to work}

The respondents were asked a series of questions to ascertain the effect of the Monetisation Policy on employees' attitude to work in the Nigerian federal civil service. When the respondents were asked whether the Monetisation Policy has helped to enhance their work motivation, the majority (57.3\%) said 'yes', 23.6\% said they were not sure and 19.1\% said 'no'. In terms of whether the introduction of the Monetisation Policy has encouraged them to remain in their jobs, the majority (56.9\%) of the respondents answered 'yes', $26.6 \%$ indicated that they were not sure and $16.5 \%$ said 'no'. With regard to whether monetisation has helped to reduce employees' work-related stress, $63.3 \%$ said 'certainly', $25.6 \%$ said 'doubtful' and $11.1 \%$ said 'not at all'.

When the respondents were asked to indicate the option that best described the effect of monetisation on them, the majority $(54.4 \%)$ indicated enhanced morale, $26.2 \%$ of the respondents indicated increased level of apathy, $16.4 \%$ indicated increased frustration over conditions of service, while $3 \%$ of the respondents indicated other options (Table 2-A1). Evidently, the analysed data revealed that the majority of the respondents were of the view that the Monetisation Policy has helped to enhance employee motivation and morale, and that it has helped to encourage employees to remain in their jobs. The data equally showed that the Monetisation Policy has helped to reduce employee work-related stress.

\section{Effect of the Monetisation Policy on employees}

The third specific objective of the study was to investigate whether the Monetisation Policy had a homogeneous effect on employees in the Nigerian federal civil service. To ascertain this, the respondents were asked whether employees with higher monetised benefits were more likely to experience better work-life balance in terms of meeting work challenges and family demands. Most (70.9\%) of the respondents answered 'certainly', $21.8 \%$ said 'doubtful' and $7.2 \%$ said 'not at all' (Table 3-A1). This shows that the majority of the respondents stated that employees with higher monetised benefits experienced better work-life balance in terms of meeting work challenges and family demands.

TABLE 2: Chi-square test of Hypothesis 1.

\begin{tabular}{lccc}
\hline Variable & Value & $d f$ & Asymp. Sig. (2-sided) \\
\hline Pearson's chi-square & 56.604 & 4 & 0.000 \\
\hline
\end{tabular}

$d f$, degrees of freedom; Asymp. Sig., asymptotic significance.

Dependent variable $=$ increased employee performance; significant at level of 0.05.

\section{Testing of hypotheses}

H1: There is a significant relationship between the Monetisation Policy and increased employee performance in the federal civil service in Imo State.

Table 2 contains a chi-square test of Hypothesis 1, which states that there is a significant relationship between the Monetisation Policy and increased employee performance in the federal civil service in Imo State. The chi-square test shows the $p$-value $(0.000)$ for $X^{2}=56.604$ with $d f=4<0.05$. As the $p$-value is $<0.05$, Hypothesis 1 is accepted:

H2: Employees with higher monetised benefits are more likely to perform better than employees with lower monetised benefits in the federal civil service in Imo State.

Table 3 contains a correlation test of Hypothesis 2, which states that employees with higher monetised benefits are more likely to perform better than employees with lower monetised benefits in the federal civil service in Imo State. The test shows a statistically significant positive correlation ( $p=0.006, r=0.087$ ) between higher monetisation benefits and employee performance. As the $p$-value $<0.05$, Hypothesis 2 is accepted.

\section{Discussion of findings}

This study specifically investigated the effects of the Monetisation Policy on employee pay packages and on employees' attitude to work. The study also investigated the possibility of a homogeneous effect of the Monetisation Policy on employees. The findings revealed that the Monetisation Policy has helped to enhance employee pay packages, employee motivation, employee morale and employee retention rate. The study found that the Monetisation Policy has helped to reduce employee workrelated stress. These assertions are premised on the responses of the majority $(59 \%, 57.3 \%, 56.9 \%, 54.4 \%$ and $63.3 \%$ ) of the respondents to questionnaire items that address the research objectives.

Hypothesis 1, which states that there is a significant relationship between the Monetisation Policy and increased employee performance in the federal civil service in Imo State, was tested using chi-square statistics. The chi-square test showed a significant relationship $(p<0.05)$ between the Monetisation Policy and increased employee performance (0.000) for $\left(X^{2}=56.604, d f .=4, p=0.000\right)$. Hence, Hypothesis 1 was accepted. The findings are consistent with the findings of Saka (2012), that the new salary package through monetisation increases productivity and output.

TABLE 3: Pearson's product-moment correlation test of Hypothesis 2.

\begin{tabular}{|c|c|c|c|}
\hline Correlations & Description & Monetisation Policy and worker motivation & Higher monetised benefits and employee performance \\
\hline \multirow[t]{3}{*}{ Monetisation Policy and worker motivation } & Pearson's correlation & 1 & $0.087 \dagger$ \\
\hline & Sig. (2-tailed) & - & 0.006 \\
\hline & $N$ & 1007 & 1007 \\
\hline \multirow{3}{*}{$\begin{array}{l}\text { Higher monetised benefits and employee } \\
\text { performance }\end{array}$} & Pearson's correlation & $0.087 \dagger$ & 1 \\
\hline & Sig. (2-tailed) & 0.006 & - \\
\hline & $N$ & 1007 & 1007 \\
\hline
\end{tabular}

Sig., significance.

$\dagger$, Correlation is significant at the 0.05 level (2-tailed). 
Hypothesis 2, which states that employees with higher monetised benefits are more likely to perform better than employees with lower monetised benefits in the federal civil service in Imo State, was tested. The test results showed a statistically significant positive correlation $(p=0.006)$ between higher monetisation benefits and employee performance, therefore Hypothesis 2 was accepted. The majority $(70.9 \%)$ of the respondents affirmed that employees with higher monetised benefits were more likely to experience better work-life balance in terms of meeting work challenges and family demands.

This result suggests that employees who enjoy higher monetised benefits are better placed to handle work challenges and family demands more effectively. In other words, employees with higher monetised benefits are more likely to be more motivated to perform their work duties better than employees with lower monetised benefits. The social exchange theory explains this phenomenon by postulating that employees are likely to adjust their work behaviour according to their perception of fairness or unfairness in the distribution of organisational rewards. Thus, those who receive more rewards (such as higher monetised benefits) or perceive fairness in the distribution of rewards will respond positively with high commitment and performance, whereas employees who perceive unfairness or receive a lower ratio of rewards may show hostility by reducing their job effort.

\section{Conclusion}

The introduction of the Monetisation Policy by the Obasanjoled administration was necessitated by the rising cost of maintaining the Nigerian civil service and by the declining performance of the civil servants, which hampered national development. The Monetisation Policy was therefore introduced to address these challenges. The Monetisation Policy was received with high expectations and, like previous reform policies, views and reservations have been expressed about the efficacy of the policy. This study therefore considered it pertinent to investigate the effects of the Monetisation Policy on employee performance in the Nigerian civil service, with particular reference to the federal civil service in Imo State.

The conclusion that can be drawn from the study is that the Monetisation Policy has had a positive effect on employee pay packages, which has probably induced enhanced work efforts directed towards achieving more pay increases through job promotion and higher monetised benefits. The enhanced pay packages have also helped to maintain and even to increase the employee retention rate in the Nigerian civil service. This study concludes that the Monetisation Policy has helped to enhance employee motivation and morale, and to reduce employee work-related stress, which are vital indicators of work efficiency. These factors do not only affect the contextual performance of the civil servants, but also predispose their task performance. This study therefore concludes that the Monetisation Policy has had positive effects on employee performance in the Nigerian civil service, particularly in the federal civil service in Imo State. The researchers recommend that the Monetisation Policy should be sustained. It is also recommended that the government should introduce other measures aimed at enhancing the motivation of employees who receive lower monetised benefits so as to further improve the overall performance of the Nigerian civil service.

\section{Acknowledgements}

The authors wish to acknowledge all the authors of the cited works.

\section{Competing interests}

The authors declare that they have no financial or personal relationships that may have inappropriately influenced them in writing this article.

\section{Author's contributions}

Theoretical work was conceptualised and contextualised by D.C.U., while the fieldwork and data collection were performed by C.O.

\section{Ethical consideration}

This article followed all ethical standards for carrying out research without direct contact with human or animal subjects.

\section{Funding}

This research received no specific grant from any funding agency in the public, commercial or not-for-profit sectors.

\section{Data availability statement}

Data sharing is not applicable to this article as no new data were created or analysed in this study.

\section{Disclaimer}

The views and opinions expressed in this article are those of the authors and do not necessarily reflect the official policy or position of any affiliated agency of the authors.

\section{References}

Adebayo, A., 2000, Principles and practice of public administration in Nigeria, Spectrum Books, Ibadan.

Adeleke, O.A., 2010,'Exploration of the implications of monetization of workers' fringe benefits in a Nigerian higher institution', Research Journal of Social Sciences 5(1), 35-51, viewed 12 October 2018, from https://www.aensiweb.net/AENSIWEB/ rjss/rjss/2010/35-51.pdf.

Aluko, M.E., 2003, The monetisation of fringe benefits in the Nigerian public service, viewed 15 January 2018, from https://dawodu.com/aluko61.htm.

Ayapere, P., 2015, 'The effect of monetization on federal civil servants in Nigeria', Public Policy and Administration Research 5(1), 103-135, viewed 21 September 2018, from https://citeseerx.ist.psu.edu/viewdoc/download?doi=10.1.1.672.426 \&rep=rep1\&type=pdf

Besley, T. \& Persson, T., 2010, 'State capacity, conflict and development', Econometrica78(1), 1-34, viewed 18 September 2018, from https://doi.org/10.3982/ECTA8073 
Borman, W.C. \& Motowildo, S.J., 1993, 'Expanding the criterion domain to include element of contextual performance', in N. Schmit \& W.C. Borman (eds.), Personnel selection in organizations, pp. 71-98, Jossey-Bass, San Francisco.

Borman, W.C. \& Motowildo, S.J., 1997,'Task performance and contextual performance: The meaning for personnel selection research', Human Performance 10(2), 99-109, viewed 10 August 2018, from https://.doi.org/10.1207/s15327043hup1002_3

Calderon, C., 2009, Infrastructure and growth in Africa: Policy research Working Paper No. 4914, viewed 16 September 2018, from https://openknowledge.worldbank. org/handle/10986/6988

Campbell, J., 1990, 'Modeling the performance prediction in industrial and organizational psychology', in M.D. Dunnette \& L.M. Hough (eds.), Handbook of industrial and organizational psychology, vol. 1, pp. 687-732, Consulting Psychology Press, Palo Alto viewed 08 August 2018, from https://www.scirp.org/(S(i43dyn45teexjx455qlt3d2q))/ reference/ReferencesPapers.aspx?ReferencelD $=1696235$

Certain Political, Public and Judicial Office Holders (Salaries and Allowances, Etc.) Act of 2002. In Federal Ministry of Information and National Orientation (2013). The Obasanjo reforms: Monetisation policy, pp. 2-3, Production, Publications \& Documentation Department, Abuja.

Cherry, K., 2016, What is social exchange theory? How does social exchange theory influence relationships?, viewed 12 January 2018, from https://www.verywell. com/what-is-social-exchange-2795882

Dabos, G.E. \& Rouseau, D.M., 2004, 'Mutuality and reciprocity in the psychological contract of employees and employers', Journal of Applied Psychology 89(1) 52-71, viewed 12 August 2018, from https://www.researchgate.net/profile/ Denise_Rousseau/publication/8881161_Mutuality_and_Reciprocity_in_the Psychological_Contracts_of_Employees_an

Fayomi, I.O., 2013, 'Monetization policy in Nigeria public service: The perspectives and challenges', International Journal of Educational Research and Development 2(5), 105-113, viewed 22 June 2018, from https://www.ajol.info/index.php/ ijdmr/article/viewFile/120976/110405.

Federal Government of Nigeria, 2014, Appropriation Act of 2014, viewed 04 January 2018, from www.budgetoffice.gov.ng/pdfs/2014-appriationact/2.summary_OSGF.pdf.

Federal Ministry of Information and National Orientation, 2013, The Obasanjo reforms: Monetisation policy, Production, Publications \& Documentation Department, Abuja.

Federal Republic of Nigeria, 1995, Review panel on the Civil Service Reform: Main report, The Presidency, Abuja.

Greenberg, J., 1990, 'Organizational justice: Yesterday, today and tomorrow', Journa of Management 16(2), 399-432. https://doi.org/10.1177/014920639001600208

Moorman, R.H., Blakely, G.L. \& Niehoff, B.P., 1998, 'Does perceived organizational support mediate the relationship between procedural justice and organizational citizenship behaviour?', Academy of Management Journal 41, 351-357, viewed 21 June 2018, from https://130.18.86.27/faculty/warkentin/SecurityPapers/ Merrill/MoormanBlakelyNiehoff1998_AMJ41_3_POS_OrgJust_OCB.pdf.

Motowildo, S.J. \& Schmit, M.J., 1999, 'Performance assessment in unique jobs', in D.R. Ilgen \& E.D. Pulakos (eds.), The changing nature of job performance: Implication for staffing, motivation and development, pp. 56-86, Jossey-Bass, San Francisco.

National Bureau of Statistics, 2012, Nigeria Poverty Profile 2010, viewed 03 December 2018, from www.nigeranstat.gov.ng/pdfuploads/NigeraPovertyProfile2010.pdf.

National Population Commission, 2010, 2006 Population and housing census: Population distribution by sex, LGA \& Senatorial district, priority table, vol. III, New Dimension Publishers, Abuja.
National Salaries, Incomes and Wages Commission, 2010, Historical perspective on salary and wage review, viewed 12 January 2018, from https://www.nsiwc.gov. salary and wage review, view.
ng/Historical_Perspective.php.

Nwanolue, B.O.G. \& Iwuoha, V.C., 2012, 'The Nigerian civil service and promotion of sustainable human development: A critical analysis', Arabian Journal of Business and Management Review 1(9), 12-21, viewed 22 July 2018, from https://www. arabianjbmr.com/pdfs/OM_VOL_1_(9)/2.pdf.

Office of the Head of the Civil Services of the Federation (OHCSF), 2013, Monetization Policy, viewed 10 January 2018, from https://www.ohcsf.gov.ng/monetization. html.

Ogunna, A.E.C., 1999, Public administration in Nigeria: Theory and practice, Great Versatile Publishers, Owerri.

Okafor, L.C., 2014, 'The monetization policy and organizational citizenship behaviour in Nigeria: A situation analysis', International Journal of Arts and Commerce 3(9), 27-39, viewed 27 November 2018, from https://ijac.org.uk/images/frontlmages/ gallery/Vol._3_No._9/3._27-39.pdf

OMICS International, 2014, Monetization, viewed 11 November 2018, from https:// research.omicsgroup.org/index.php/Monetization

Roe, R.A., 1999, 'Work performance: A multiple regulation perspective', in C.L. Copper \& I.T. Roberston (eds.), International review of industrial and organizational psychology, vol. 14, pp.231-335, Wiley, Chichester.

Saka, A., 2012, 'The macroeconomic impact of monetization on the Nigerian economy', Journal of African Studies and Development 4(8), 185-192, viewed 22 November 2018, from https://www.academicjournals.org/app/webroot/article/ article1380036192_Saka.pdf.

Schacter, M., 2002, Not a toolkit: Practitioners' guide to measuring of public program, Institute of Governance, Ottawa, viewed 13 December 2018, from https://www. rareplanet.org/sites/rareplanet.org/files/Mark_Schacter_Not_a_Toolkit.pdf

Schiavo-Campo, S. \& Sundaram, P., 2001, To serve and to preserve: Improving public administration in a competitive world, Asia Development Bank, Manila, viewed 20 October 2018, from https://www.adb.org/publications/serve-and-preserveimproving-public-administration-competitive-world.

Shaw, J., Dineen, B., Fang, R. \& Vallella, R., 2009, 'Employee-organization exchange relationship, HRM practice and quit rates, good and poor performers', Academy of Management Journal 52(5), 1016-1033, viewed 07 December 2018, from https:// www.polyu.edu.hk/mm/jason/doc/Shaw-Dineen-Fang-Vellella\%202009\%20 AMJ.pdf.

Van Dyne, L. \& LePine, J., 1998, 'Helping and voice extra-role behaviours: Evidence of construct and predictive validity', Academy of Management Journal 41(1) 108-119, viewed 18 August 2018, from https://www.jstor.org/stable/256902? seq=1\#page_scan_tab_contents

Wayne, S., Shore, L., Bommer, W. \& Tetrick, L., 2002, 'The role of fair treatment and rewards in perception of organizational support and leader-member exchange', Journal of Applied Psychology 87(3), 590-598, viewed 03 December 2018, from https://www.mendeley.com/papers/role-fair-treatment-rewards-perceptionsorganizational-support-leadermember-exchange/.

Werner, J.M., 2000, 'Implications of organizational citizenship behaviour and contextual performance for human resource management', Human Resource Management Review 10(1), 3-24. https://doi.org/10.1016/S1053-4822(99)00036-4

Williams, K.D. \& Karau, S.J., 1991, 'Social loafing and social compensation: The effects of expectations of co-worker performance', Journal of Personality and Socia Psychology 61(4), 570-581, viewed 20 June 2018, from https://www.ncbi.nlm.nih. gov/pubmed/1960649. 


\section{Appendix 1}

\section{Survey data}

TABLE 1-A1: Respondents' views on the effect of the Monetisation Policy on employee pay packages.

\begin{tabular}{lcc}
\hline Questionnaire item and response categories & Frequency & $\mathbf{\%}$ \\
\hline Has the Monetisation Policy enhanced your pay package? & - & - \\
Yes & 594 & 59.0 \\
Not sure & 229 & 22.7 \\
No & 184 & 18.3 \\
\hline Total & $\mathbf{1 0 0 7}$ & $\mathbf{1 0 0 . 0}$ \\
\hline
\end{tabular}

TABLE 2-A1: Respondents' views on the effect of the Monetisation Policy on workers' attitude to work.

\begin{tabular}{lcc}
\hline Questionnaire item and response categories & Frequency & $\mathbf{\%}$ \\
\hline Has the Monetisation Policy helped to enhance your work motivation? & - & - \\
Yes & 577 & 57.3 \\
Not sure & 238 & 23.6 \\
No & 192 & 19.1 \\
Total & 1007 & 100.0 \\
Has the Monetisation Policy encouraged you to remain on the job? & - & - \\
Yes & 573 & 56.9 \\
Not sure & 268 & 26.6 \\
No & 166 & 16.5 \\
Total & 1007 & 100.0 \\
Has the Monetisation Policy helped to reduce your work-related & - & - \\
stress? & & \\
Certainly & 637 & 63.3 \\
Doubtful & 258 & 25.6 \\
Not at all & 112 & 11.1 \\
Total & 1007 & 100.0 \\
Which one of the options best describes the effect of the & - & - \\
Monetisation Policy on you? & & \\
Enhanced morale & 548 & 54.4 \\
Increased level of apathy & 264 & 26.2 \\
Increased frustration over conditions of service & 165 & 16.4 \\
Others & 30 & 3.0 \\
Total & 1007 & 100.0 \\
\hline
\end{tabular}

TABLE 3-A1: Respondents' view on the effect of the Monetisation Policy on employees.

\begin{tabular}{lcc}
\hline Questionnaire item and response categories & Frequency & $\%$ \\
\hline $\begin{array}{l}\text { Employees with higher monetised benefits are more likely to } \\
\text { experience better work-life balance in terms of meeting work } \\
\text { challenges and family demands: }\end{array}$ & & \\
Certainly & 714 & 70.9 \\
Doubtful & 220 & 21.8 \\
Not at all & 73 & 7.2 \\
\hline Total & 1007 & $\mathbf{1 0 0 . 0}$ \\
\hline
\end{tabular}

